\title{
Particulate bioglass in the regeneration of alveolar bone in dogs: clinical, surgical and radiographic evaluations
}

\author{
Alexandre Couto Tsiomis ${ }^{1}$, Andréa Pacheco Batista Borges ${ }^{2}$, Ana Paula Falci Daibert ${ }^{1}$, \\ Tatiana Schmitz Duarte ${ }^{1}$, Emily Correna Carlo Reis ${ }^{1}$, Tatiana Borges Carvalho ${ }^{1}$
}

\begin{abstract}
Bone loss, either by trauma or other diseases, generates an increasing need for substitutes of this tissue. This study evaluated Bioglass as a bone substitute in the regeneration of the alveolar bone in mandibles of dogs by clinical, surgical and radiological analysis. Twenty-eight adult dogs were randomly separated into two equal groups. In each animal, a bone defect was created on the vestibular surface of the alveolar bone between the roots of the fourth right premolar tooth. In the treated group, the defect was immediately filled with bioglass, while in the control, it remained unfilled. Clinical evaluations were performed daily for a week, as well as x-rays immediately after surgery and at 8,14 , 21, 42, 60, 90 and 120 days post-operative. Most animals in both groups showed no signs of inflammation and wound healing was similar. Radiographic examination revealed a gradual increase of radiopacity in the region of the defect in the control group. In the treated group, initial radiopacity was higher than that of adjacent bone, decreasing until 21 days after surgery. Then it gradually increased until 120 days after surgery, when the defect became undetectable. The results showed that Bioglass integrates into bone tissue, is biocompatible and reduced the period for complete bone regeneration.
\end{abstract}

Key words: Biomaterials, bone substitute, bone regeneration.

\section{RESUMO}

\section{Avaliação clinico-cirúrgica e radiográfica do biovidro particulado na regeneração do osso alveolar de cães}

A perda óssea, tanto por traumas quanto por outras afecções, gera uma necessidade cada vez maior do uso de substitutos para este tecido. Este trabalho avaliou o biovidro como substituto ósseo na regeneração do osso alveolar da mandíbula de cães, por meio de análises clínico-cirúrgica e radiográfica. Foram utilizados 28 cães adultos, separados aleatoriamente em dois grupos iguais. Em cada animal, foi criado um defeito ósseo na superfície vestibular do osso alveolar, entre as raízes do dente quarto pré-molar direito. No grupo tratado, o defeito foi imediatamente preenchido com biovidro, enquanto no controle, este permaneceu sem preenchimento. Foram realizadas avaliações clínicas diárias durante uma semana, assim como radiografias logo após a cirurgia e aos oito, 14, 21, 42, 60, 90 e 120 dias do pósoperatório. A maioria dos animais dos dois grupos não apresentou sinais de inflamação e a cicatrização da ferida cirúrgica ocorreu de forma semelhante. O exame radiográfico revelou aumento gradual da radiopacidade na região do defeito no grupo controle. No grupo tratado, observou-se inicialmente radiopacidade superior à do osso adjacente, diminuindo até os 21 dias de pós-operatório, voltando a aumentar gradativamente até os 120 dias do pós-cirúrgico, quando o defeito tornou-se imperceptível. O biovidro é integrado ao tecido ósseo, é biocompatível e diminuiu o período para a completa regeneração óssea.

Palavras-chave: Biomaterial, substituto ósseo, regeneração óssea.

Recebido para publicação em fevereiro de 2009 e aprovado em dezembro de 2010

${ }^{1}$ Veterinarian, MSc. Universidade Federal de Viçosa, Departamento de Veterinária. Av PH Rolfs, s / n, Campus, 36570-000, Viçosa, Minas Gerais, Brazil.tsiomis@yahoo.com.br; apdaibert@hotmail.com; tduarte_br@yahoo.com.br; emilycarlo@yahoo.com.br

${ }^{2}$ Veterinarian, PhD. Universidade Federal de Viçosa, Departamento de Veterinária. Av. PH Rolfs, s/ n, Campus, 36570-000, Viçosa, Minas Gerais, Brazil. andrea@ufv.brAuthor for correspondence. 


\section{INTRODUCTION}

Currently, the treatment of dental and oral diseases comprises a significant part of clinical-surgical practice of small animals. As a result, the evolution of dentistry and oral surgery as specialties has followed the development of Veterinary Medicine and justifies the large number of studies recently undertaken on the subject (Dorn, 1998, Carlo et al., 2006).

Cranio-maxillofacial traumas are a major cause of fractures with bone loss in both human and veterinary medicine. In these cases, the use of bone substitutes is necessary to maintain continuity of the fragments and to provide a matrix for the deposition and migration of osteoprogenitor cells, allowing the complete bone regeneration (Carlo et al., 2007, Duarte et al., 2007). Autografts are commonly used, but have major drawbacks such as limited availability and morbidity that affect the donor site (Zamet et al. 1997, Orr et al., 2001). On the other hand, allografts have disadvantages as the risk of disease transmission and the possibility of an immune response (Jensen et al., 1996, Schmitt et al., 1997). Synthetic grafts, however, are available in any amount and do not have the disadvantages mentioned above (Zamet et al., 1997).

Periodontal disease is another important condition. It is an oral infection resulted from the chronic retention of bacteria in the dento-gingival junction leading to loss of alveolar bone (Dorn, 1998). The regeneration of bone defects caused by periodontal disease is still a therapeutic challenge, and the use of synthetic grafts is an alternative to promote bone healing (Zamet et al., 1997).

Studies using bioglass as bone substitute have shown its great capacity to bind with both bone and soft tissues, which is advantageous compared with other bioactive ceramics (Zamet et al. 1997; Laurence $\&$ Hillier, 2003). Studies in rabbits showed that it is nontoxic, biocompatible and integrates into the bone tissue (Turunen et al. 1997, Piattelli et al., 2000). Some authors have suggested that Bioglass has osteoinductive effect, namely, the capacity to induce differentiation of cells into osteoblasts (Oonish et al. 1999; Xynus et al., 2001). Later, however, it was proven that it is only osteoconductive, serving as a matrix for migration and proliferation of osteoprogenitor cells (Vogel et al. 2001; Carlo et al., 2007).

The aim of this study was to evaluate the effect of particulate bioglass on the regeneration of alveolar bone. For this, the material was implanted in an intrabony defect created in mandibles of dogs and regeneration of alveolar bone was assessed by clinical, surgical and radiological analysis.

\section{MATERIAL AND METHODS}

A total of 28 clinically healthy dogs, males and females, of no specific breed, weighing 10-15 kg, free of periodontal disease, from the experimental kennel of the Veterinary Department, Federal University of Viçosa, were used in this study. The animals were kept in individual cages and fed a standard diet ${ }^{3}$ twice daily and water ad libitum. The animals were randomly separated into two equal groups, where one group received bioglass (treated group) and the other was used as control.

The animals were treated with spiramycin (75.000UI/ $\mathrm{Kg})$ and metronidazole $(12.5 \mathrm{mg} / \mathrm{kg})^{4}$ orally, three days before surgery. After water and food deprivation for twelve hours, they were sedated with intravenous acepromazine ${ }^{5}$ at a dose of $0.1 \mathrm{mg} / \mathrm{kg}$ (IV). The anesthetic protocol consisted of induction with sodium thiopental ${ }^{6}(12.5 \mathrm{mg} /$ $\mathrm{kg}, \mathrm{IV})$ and maintained with a halothane $\mathrm{7}^{7}$-oxygen mixture. The animals were placed in the left lateral recumbency position, then a bite-block was inserted to facilitate the manipulation of the oral cavity and then teeth and gums were cleaned with $0.12 \%$ chlorhexidine solution ${ }^{8}$. A mucoperiosteal flap was performed with a scalpel blade $\left(n^{\circ} .15\right)$, by an incision immediately apical to the mucogingival line of the mandibular fourth premolar in the right disto-mesial direction. Two incisions in the corono-apical direction were performed on distal and mesial margins of the same tooth. The flap was then moved to expose the buccal surface of the mandible (Fig. 1A). A defect of approximately $6 \times 5 \times 5 \mathrm{~mm}$ was created between the roots of the fourth premolar (Fig. 1B) with a low speed trephine drill ${ }^{9}$ and constant irrigation with $0.9 \%$ saline solution.

In the treated group, the defect was immediately filled with bioglass particles ${ }^{10}$ (Fig. 1C).

In dogs in the control group, the defect remained untreated. In all animals, the mucoperiosteal flap was repositioned and sutured with continuous Polyglactin 4$0^{11}$ (Fig. 1D).

The animals were treated with spiramycin (75.000UI/ $\mathrm{Kg})$ and metronidazole $(12.5 \mathrm{mg} / \mathrm{kg})^{12}$ orally, three days before surgery. Post-operatively, were treated for 3 days with spiramycin and metronidazole, as preoperatively, and then with subcutaneous enrofloxacin ${ }^{13}$ at $10 \mathrm{mg} / \mathrm{kg}$ once daily for seven days. Surgical wounds were cleaned daily with $0.12 \%$ chlorhexidine solution until healing. The anti-inflammatory ketoprofen ${ }^{14}$ was administered subcutaneously at a dose of $1.1 \mathrm{mg} / \mathrm{kg}$

\footnotetext{
${ }^{3}$ Selection Special Croc ${ }^{\circledR}$ - Royal Canin ${ }^{4}$ Estomorgyl $10 \circledast$ - Merial

${ }^{5}$ Acepran ${ }^{1}$ 1\% - Univet

${ }^{6}$ Tiopental@ $19-$ Cristáli

Tiopental® $1 \mathrm{~g}-$ Cristáli

${ }^{8}$ Periogardâ - Colgate-Palmolive
} 



Figure 1. Stages of the surgical procedure in a dog mandible. A. Exposure of the buccal surface of the right mandible through a full mucoperiosteal flap in the region of the fourth premolar; B. Experimental bone defect (arrow) of approximately $6 \times 5 \mathrm{~mm}$; C. Completely filled bone defect by particulate bioglass (arrow); D. Mucoperiosteal flap repositioned and sutured (asterisk).

every 24 hours over three days after surgery. The animals were fed pasty food during two weeks postoperatively.

The local clinical examination consisted of daily observation of the surgical wound, and for two weeks, wound dehiscence and inflammatory reaction were evaluated, the latter by the presence of edema and pain. All variables except wound dehiscence were classified as severe, moderate, mild or absent. The wound dehiscence was evaluated as absent or present.

The swelling was considered mild when slight swelling was observed at the site of surgical incision, moderate, when the swelling has spread to the ventral region of the mandible, and intense when it extended across the right mandibular gingiva.

Pain was considered mild when the animal reacted to digital touch on the surgical incision, moderate when the animal was reluctant to feed and to allow the hygiene of the place. The pain was considered intense, when in addition to the characteristics of moderate pain, the animal lay in a prostrate position. In the absence of pain, the animal showed normal appetite soon after recovering from anesthesia and allowed care of the surgical site during the experimental period.

Radiographs of the operated site were taken in the lateromedial (LM) and oblique positions, of all animals immediately after surgery and on days eight, 14, 21, 42, 60, 90 and 120 postoperative, using dental radiographic film ${ }^{15}$. Thus, the process of bone regeneration could be monitored, and the time required for it could be assessed by comparing the control with the treated group.

Based on the radiographs, radiopacity was classified as absent (grade 0) and into different grades when present, comparing the experimental bone defect with the adjacent bone, considered normal. Therefore, the radiopacity was rated as less intense (grade 1), slightly lower (grade 2) similar (grade 3) or higher (grade 4) than the adjacent bone. The results were evaluated considering the pattern of radiopacity of the alveolar bone, comparing groups and dates within each group, using descriptive qualitative analysis.

\footnotetext{
${ }^{15}$ Filme radiográfico Kodac DF 58
} 


\section{RESULTS AND DISCUSSION}

During surgery, it was observed that the bioglass in the particulate form facilitated its implementation, which agrees with Vogel et al. (2001), who made a similar observation and reported it to be particularly useful for the treatment of bone defects. Furthermore, the great capacity of Bioglass cohesion resulted in adequate compaction of the material and consequently in bleeding reduction. These findings are consistent with those reported by DeForge (1997) and Froum et al. (1998), who described the cohesion ability of Bioglass upon contact with bodily fluids, which prevents migration of material from the surgical site (Fig. 1C) in addition to its hemostatic effect. This effect is due to the electronegative surface of the silica gel layer which can absorb water quickly, because molecules of water can form a hydrogen bonding with the hydroxyl group of silicic acid.

Most animals of the treated $(78.57 \%)$ and control $(57.14 \%)$ groups showed mild swelling in the first two days post-operatively. Three animals in the control group had moderate swelling on the first day after surgery. Swelling was not observed seven days after surgery. The control group showed delayed recovery in relation to swelling. On the first day after surgery, four animals in the treated group and six control animals had mild pain and only one animal in the treated group had moderate pain. Pain receded rapidly, and by the third day after surgery all animals from both groups showed no signs of it.

Brief and mild inflammatory response, as reported by Borges et al. (2000), was observed in both groups and attributed to the manipulation of periodontal tissue during surgical intervention. Infection signs were not observed, unlike reported by Alliot et al. (1999), who deduced that gingival inflammation observed in their experiments was due to lack of proper oral hygiene in the dogs. In this study, the daily hygiene of the surgical wound, the use of antibacterial and anti-inflammatory agents and diet with pasty ration are likely to be responsible for the best results relative to those reported by Alliot et al. (1999). Still, according to Stoor et al. (1998) and Allan et al. (2001), Bioglass has demonstrated antibacterial activity as a result of reactions on the surface of this biomaterial that culminate in an increase in local $\mathrm{pH}$ and osmotic pressure, hence, reducing the viability of supra and subgingival bacteria. It is suggested that this bioglass characteristic is one of the responsible factors for better clinical outcomes observed in the treated group compared with the control group in this experiment.

None of the animals in the treated group showed signs of bleeding after surgery, occurring mildly in four animals of the control group, but, persisted for up to two days after surgery. This observation confirms the hemostatic effect of bioglass suggested by DeForge (1997) and Froum et al. (1998).

Suture dehiscence was not observed in any animal in this study. Wound healing progressed as expected. It was complete at 10 days after surgery, when the stiches were removed.

Radiographic images of animals in the control group taken immediately after surgery showed grade 0 radiopacity in the defect region, since the defect created remained unfilled (Fig. 2A). However, in the treated group, during the same period, radiopacity was higher than in the adjacent bone (grade 4). This is explained by the high
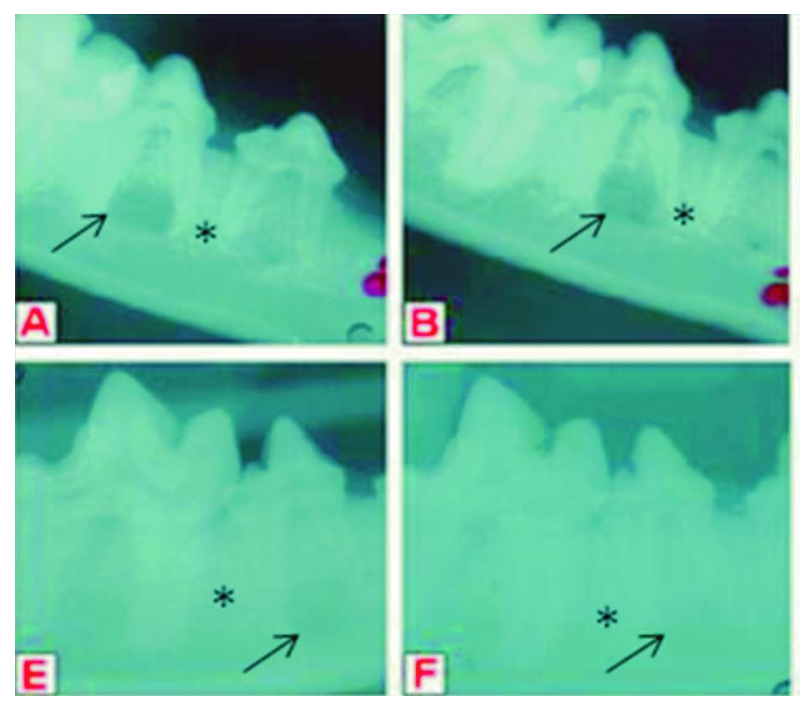
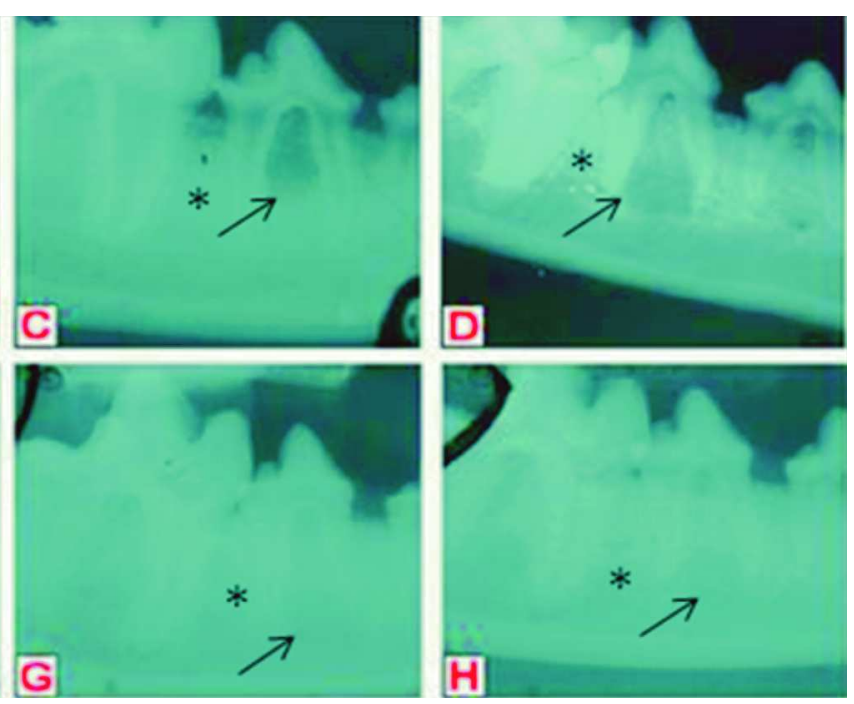

Figure 2. Lateral-medial radiographs of the region of the fourth lower right premolar in mandibles of different dogs in the control group. A. Immediately after surgery; B. 8 days postoperatively; C. 14 days postoperatively; D. 21 days postoperatively; E. 42 days postoperatively; F. 60 days postoperatively; G. 90 days postoperatively; H. 120 days postoperatively. Observe the radiopacity of the defect (arrows) relative to the adjacent bone (*), ranging from absent (grade 0) in A to slightly lower in $\mathbf{H}$. 
atomic number of elements in the bioglass composition, as in other ceramics (Borges et al., 2000). Radiographs of the treated group, taken shortly after surgery, showed that bioglass was properly implanted in the recipient site, with no sign of migration of the material (Fig. 3A), as seen in the peri-operative period.

In the control group, at 8 (Fig. 2B) and 14 days (Fig. 2C) after surgery, radiographic features were similar to those described above. According to Borges et al. (2000), this can be explained by the fact that in every bone healing process, connective tissue is initially formed in the lesion focus, whose radiopacity is insufficient to be noticeable in the radiographic examination. The evaluation of radiographs from the $21^{\text {st }}$ post-operative day of the control group showed increased radiopacity of the bone defect, which was classified as grade 1 (Fig. 2D). At 42 days, the defect was still apparent, but there was rounding of their edges with radiopacity grade 2 in the periphery and grade 1 in the center. The increased radiopacity suggests that the process of bone regeneration began at the periphery of the defect, progressing toward its center (Fig. 2E). On the $60^{\text {th }}$ day after surgery, the bone defect was still visible radiographically, with radiopacity grade 2 . The same was observed at 90 and 120 days post-operatively (Fig. 2F, $2 \mathrm{G}$ and $2 \mathrm{H}$ ). Therefore, during the experiment, there was no complete filling of the defect with bone tissue in the control group.

In the treated group, on the eighth day of the postoperative, grade 1 radiopacity was observed on the margin and grade 4 in the center of the defect, suggesting resorption of bioglass at the interface bone-material, remaining in the more central region (Fig. 3B). The reduction in radiopacity at the interface can also suggest the formation of connective tissue or even immature bone of low density, as suggested by Yamamuro et al. (1994) and Duarte et al. (2007), indicating the beginning of the bone regeneration process.

At 14 and 21 days after surgery, similar images were observed in all animals. Radiographs obtained on those dates showed, by the evolution of radiopacity, the evolution of the bone regeneration process. We found greater resorption of bioglass and deposition of connective tissue and/or immature bone, as well as significant reduction in the size of the defect, demonstrated by the change in its shape, from square to round (Fig. 3C and 3D). This finding suggests the formation of new bone tissue, with consequent increase in radiopacity of the defect, classified as grade 2.

At 42 days post-operative, defect size decreases, acquiring a more rounded shape. The radiopacity in the center of the defect was lower than the adjacent bone, being classified as grade 2 (Fig. 3E).

Similar picture was observed at 60 and 90 days after surgery, but with increasing reduction of the bone defect, becoming imperceptible at 120 days postoperatively. The radiopacity was classified as grade 2 at 60 and 90 days and grade 3 at 120 days (Fig. 3F, 3G and 3H). That is, at the end of the observation period, the region of bone defect showed radiographic image identical to the adjacent bone. Thus, one can say that with the implantation of bioglass, the process of alveolar bone regeneration of the mandible in dogs was faster over the defect without the use of any filling (Fetner et al. 1994; Piatelli et al., 2000).
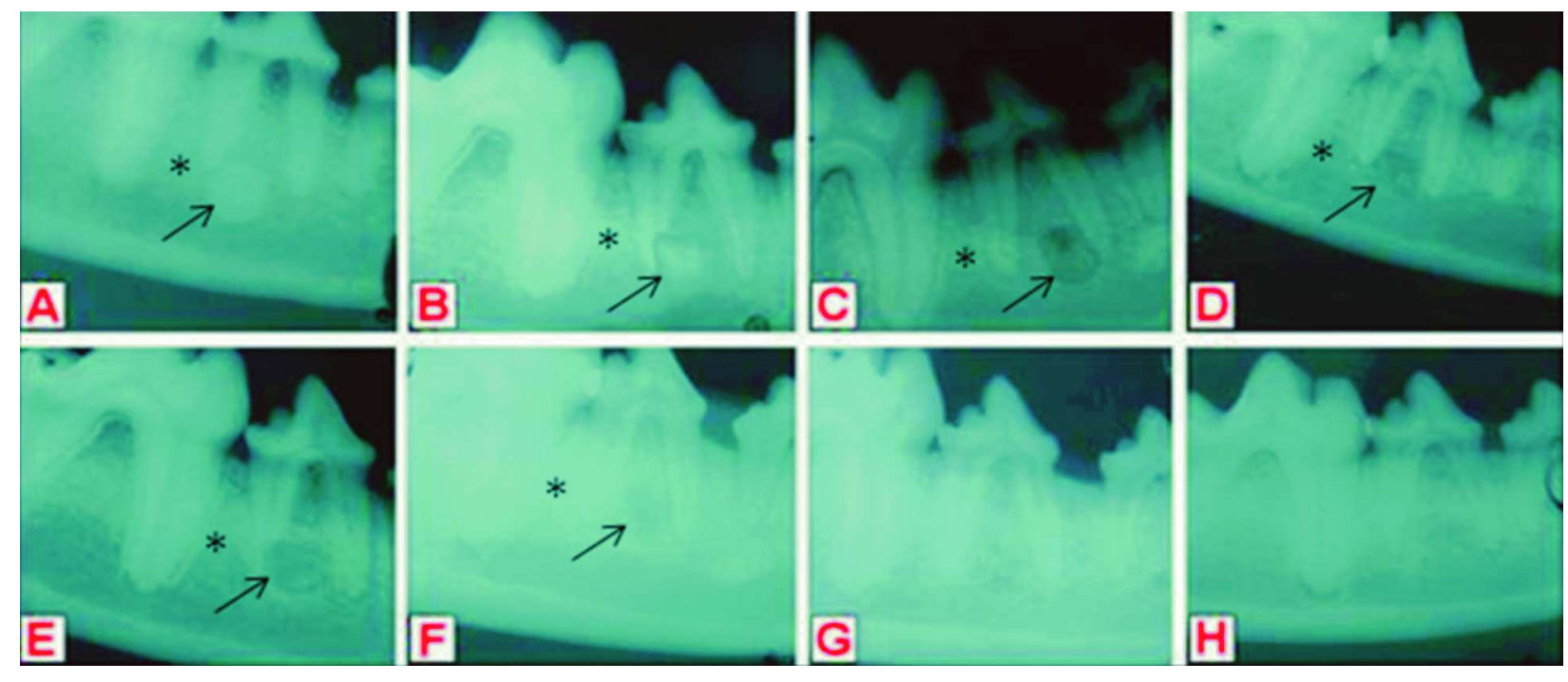

Figure 3. Lateral-medial radiographs of the region of the fourth lower right premolar in mandibles of different dogs in the treated group. A. Immediately after surgery; B. 8 days postoperatively; C. 14 days postoperatively; D. 21 days postoperatively; E. 42 days postoperatively; F. 60 days postoperatively; G. 90 days postoperatively; H. 120 days postoperatively. Observe the radiopacity of the defect (arrows) relative to the adjacent bone (*), ranging from higher (grade 4) in A, going through slightly lower (grade 2) in $\mathbf{D}$ and $\mathbf{E}$, to similar to the adjacent bone (grade 3 ) in $\mathbf{G}$ and $\mathbf{H}$. 
In all animals of this experiment, the radiographic examination showed progressive bone regeneration of the defect. In the treated group, the similarity of the radiopacity of the defect with the adjacent bone, from the $90^{\text {th }}$ day after surgery, showed complete osseointegration of bioglass and new bone formation, since the optical density is indicative of mineralized tissue formation. In the control group, bone regeneration occurred, but not in its entirety because the bone defect remained visible to the end of the experimental observation. This finding is in agreement with reports by Oonishi et al. (1999) in a study of various bone substitutes. These authors concluded that the use of bioglass allowed faster bone regeneration when compared to other materials, suggesting that this is because bioglass serve as a scaffoldfor the development of blood vessels and bone tissue, i.e., osteoconduction.

\section{CONCLUSIONS}

The clinical and surgical findings of this study indicated that bioglass has desirable characteristics of a bone substitute for the regeneration of alveolar bone in mandibles of dogs, such as hemostatic effect and facility to fit the size and shape of defects. The absence of signs of inflammation and rejection supports the hypothesis that this is a biocompatible material. Moreover, bioglass has shortened the time for complete bone regeneration, integrating into the bone tissue and demonstrating its osteoconductive property.

\section{ACKNOWLEDGEMENTS}

The authors would like to thank CNPq and FAPEMIG for funding this project.

\section{REFERENCES}

Allan I, Newman H \& Wilson M. (2001) Antibacterial activity of particulate Bioglass ${ }^{\hat{\imath}}$ against supra- and subgengival bacteria. Biomaterials, 22:1683-1687.

Alliot B, Piotrowski B, Marin P, Zahedi S \& Brunel G (1999) Regeneration procedures in immediate transmucosal implants: an animal study The International Journal of Oral \& Maxillofacial Implants, 14:841-848.

Borges APB, Rezende CMF, Ribeiro MFB, Melo EG \& Nobrega Neto PI (2000) Hidroxiapatita sintética como substituto ósseo em defeito experimental provocado no proximal da tíbia de cão: aspectos à microscopia de transmissão. Arquivo Brasileiro de Medicina Veterinária e Zootecnica, 52:616-620.

Carlo EC, Borges APB, Fófano G, Fontes EB, Sena MP \& Carvalho TB (2006) Técnica da regeneração tecidual guiada (RTG) na reparação da mandíbula de cão. Revista Ceres, 53:376-384.

Carlo EC, Borges APB, Moreira JCL, Fonseca CC, Pontes KCS \& Duarte TS (2007) Avaliação do efeito osteoindutor da hidroxiapatita sintética e do biovidro particulado implantados em tecido subcutâneo de cão. Revista Ceres, 54:492-501.
DeForge DH (1997) Evaluation of Bioglass/Perioglass (Consil) synthetic bone graft particulate in the dog and cat. Journal of Veterinary Dentistry, 14:141-145.

Dorn AS (1998) Introdução para a odontologia veterinária. In: Slatter D (Ed). Manual de Cirurgia de Pequenos Animais. São Paulo, Manole. p.2726-2732.

Duarte TS, Borges APB, Lavor MSL, Filgueiras R, Tsiomis AC, Fófano G, Odenthal ME \& Pontes KCS (2007) Osteointegração da hidroxiapatita sintética no processo alveolar da mandíbula de cães: aspectos clínicos e radiográficos. Arquivo Brasileiro de Medicina Veterinária e Zootecnia, 59:114-118.

Fetner AE, Hartigan MS \& Low SB (1994) Periodontal repair using Perioglas ${ }^{\hat{a}}$ in nonhuman primates: clinical and histologic observations. Compendim of Continuing Education in Dentistry, 15:932-938.

Froum SJ, Weinberg MA \& Tarnow D (1998) Comparison of bioactive glass synthetic bone graft particles and open debridement in the treatment of human periodontal defects. A clinical study. Journal of Periodontology, 69:698-709.

Jensen SS, Aaloe M, Pinholt EM, Hjorping-hansen E, Melsen F \& Ruyter IE (1996) Tissue reaction and material characteristics of four bone substitutes. The International Journal of Oral \& Maxillofacial Implants, 11:55-66.

Laurence P \& Hillier IH (2003) Towards modeling bioactive glasses: quantum chemistry studies of the hydrolysis of some silicate structures. Computational Materials Science, 28:68-75.

Oonishi H, Hench LL, Wilson J, Sugihara F, Tsuji E, Kushitani S \& Iwaki H (1999) Comparative bone growth behavior in granules of bioceramic materials of various sizes. Journal of Biomedical Materials Research, 44:31-43.

Orr TE, Villars PA, Mitchell HP, Hsu HP \& Spector (2001) Compressive properties of cancellous bone defects in rabbit model treated with particles of natural bone mineral and synthetic hydroxyapatite. Biomaterials, 22:1953-1959.

Piattelli A, Scarano A. Piattelli M, Coraggio F \& Matarasso S (2000) Bone regeneration using bioglass: an experimental study in rabbit tibia. Journal of Oral Implantology, 26:257-261.

Schmitt JM., Buck DC, Joh S, Lynch SE \& Hollinger JO (1997) Comparison of porous bone mineral and biologically active glass in critical - sized defects. Journal of Periodontology, 68:1043-1053.

Stoor P, Soderling E \& Salonen J (1998) Antibacterial effects of a bioactive glass paste on oral microorganisms. Acta Odontologica Scandinavica, 56:161-165.

Turunen T, Peltola J, Helenius H, Yli-Urpo A \&. Happonen RP (1997) Bioactive glass and calcium carbonate granules as filter material around titanium and bioactive glass implants in the medular space of the rabbit tibia. Clinical Oral Implantology Research, 8:96-102.

Vogel M, Voigt C, Gross UM \& Muller-Mai CM (2001) In vivo comparison of bioactive glass particles in rabbits. Biomaterials, 22:357-362

Xynos ID, Edgar AJ, Buttery LD, Hench LL \& Polak JM (2001) Gene-expression profiling of human osteoblasts following treatment with the ionic products of bioglass 45S5 dissolution. Journal of Biomedical Material Research, 55:151-157.

Yamamuro T (1994) Bone bonding behavior and clinical use of AW glass-ceramic. In: Urist MR, O'Connor BT \& Burwell (Eds.) Bone grafts derivatives and substitutes. Cambridge, ButterworthHeinemann. p.245-259.

Zamet JS, Darbar UR, Griffiths GS, Bulman JS, Bragger U, Burgin W \& Newman HN (1997) Particulate bioglass as a grafting material in the treatment of periodontal intrabony defects. Journal of Clinical Periodontology, 24:410-418. 